J. Lake Sci. (湖泊科学), 2006, 18(3): $199-206$

http:// www. jlakes. org. E-mail: jlakes@ niglas. ac.cn

(c) 2006 by Journal of Lake Sciences

\title{
中国湖泊水域中磷形态转化及其潜在生态效应研究动态”
}

\author{
黄清辉 ${ }^{1}$, 王 磊 $^{2}$, 王子健 ${ }^{1 * *}$ \\ (1: 中国科学院生态环境研究中心,北京 100085) \\ (2: 中国 21 世纪议程管理中心, 北京 100089)
}

摘 要: 天然水域,尤其是富营养的浅水湖泊,沉积物中磷的释放是蓝藻水华发生、形成和持续生长的重要因素. 分析沉积 物中磷的赋存形态转化及其潜在生态效应, 有助于理解沉积物中磷的迁移转化过程及其与湖泊富营养化之间的关系. 本 文综述国内湖泊水域中磷的主要形态、来源和转化过程以及其生物有效性的研究进展. 重点讨论了近 5 年来中国东部浅 水湖泊沉积物磷的形态分析、转化和生物有效性评估的现状, 以及沉积物中磷形态与浅水湖泊富营养化之间的潜在联系. 关键词: 中国湖泊;磷形态;分级分离;生物有效性;富营养化

\section{Advance in the study on phosphorus speciation, transformation and its potential ecological effects in Chinese lakes}

\author{
HUANG Qinghui ${ }^{1}$, WANG Lei ${ }^{2} \&$ WANG Zijian ${ }^{1}$ \\ (1: Research Center for Eco-Environmental Sciences, Chinese Academy of Sciences, Beijing 100085, P. R. China) \\ (2:The Administrative Center for China's 21 Agenda, Beijing 100089, P. R. China)
}

\begin{abstract}
Release of phosphorus from sediment of natural waters, especially from those shallow lakes, are essential process in the growth and development of algae bloom. Studies on species transformation and changes in bioavailability will be helpful in understanding geochemical cycling of phosphorus in lakes and its relation to lake eutrophication. This paper summarized the recent research progresses on phosphorus speciation, transformation, phosphorus cycling in Chinese lakes, and the relevant changes in bioavailability. Recently, special attention was given to issues such as different species in sediments in eastern China shallow lakes because there were only a few works on the lakes in the west, south and north of China. Relevant research was also less found on the brackish lakes in the plateaus or lagoons in the estuarine and coastal zones. In addition, it is a pity that no work could make a breakthrough on the methods of phosphorus fractionation. There was a little advance in the study on the transformation of phosphorus species, the assessment of phosphorus release risk and its bioavailability. For example, the pattern of phosphorus release from different types of sediments in response to $\mathrm{pH}$ changes was unveiled; the approaches for laboratory and in situ measurements of bioavailable forms of phosphorus were developed, as well as the relationship between acid soluble organic phosphorus species and eutrophication were proposed. In a eutrophic shallow lake, there is an interaction relationship between algal blooms and internal phosphorus release. However, this interaction is well related to human disturbance and influenced by some natural factors, e. g. hydrodynamic processes and stormy waves. Much beneficial exploration was done on the phosphorus speciation, mobilization and transformation between sediment and water interface in many lakes in China, and a lot of hypothesises as well as new methods were also proposed in recent studies, but it still need more experimental data to testify.
\end{abstract}

Keywords : Chinese lakes; phosphorus speciation; fractionation; bioavailability; eutrophication

* 国家 863 计划(2002AA60101) 和中国科学院知识创新工程重大项目 (KZCX1-SW-12-II-32) 共同资助. 2006-01-05 收稿; 2006-02-23 收修改稿. 黄清辉, 男, 1977 年生, 博士, 讲师; 现在同济大学环境科学与工程 学院工作; E-mail: qhhuang@ mail. tongji. edu.cn.

** 联系人;E-mail: wangzj@ rcees. ac.cn. 
磷的主要无机形态是正磷酸盐、多聚磷酸盐和磷化氢. 正磷酸盐是湖泊水体最普遍存在、研究最多、通 常认为是关键的生物有效态. 多聚磷酸盐是化工产品, 也可以通过自然水解过程和某些细菌的合成而形成, 如我国学者在日内瓦湖沉积物中发现过自然形成的多聚无机磷的证据 ${ }^{[1]}$, 但是对这些聚合形态磷在湖泊 磷循环中的作用至今尚不十分清楚. 磷化氢是自然界中磷以还原形态和气态化合物存在的唯一形态 ${ }^{[2,3]}$, 尽管其在湖泊生态系统中的含量十分有限 ${ }^{[3]}$, 但是由于具有挥发性, 在元素生物地球化学循环的意义则十 分重大. 在沉积物中磷形态更为复杂, 通常可对磷形态进行分级分离来弄清沉积物磷形态及其迁移转化过 程 ${ }^{[4-6]}$, 即利用不同性质的化学提取剂, 依次提取出沉积物中某种形态/相态的磷, 达到分离的目的. 不同提 取剂的提取能力, 反映了不同的溶解性、氧化 - 还原特性以及酸碱性等理化特征,故而提取的形态能够反映 沉积物中磷的生物地球化学特征. 用化学提取的方法定义的沉积物中磷形态主要可分成以下几种: 活性的、 松散结合的或可交换的磷组分易于释放并可为藻类生长所利用; 铁/铝结合态磷 $(\mathrm{Fe} / \mathrm{Al}-\mathrm{P})$ 组分通常与沉积 物中的铝、铁/锰的氧化物/氢氧化物 (如 $\mathrm{Fe}(\mathrm{OOH})$ ) 结合在一起; 钙结合态磷 ( Ca-P) 组分常与碳酸钙吸附 的磷和钻磷酸盐沉淀相关联的; 有机磷组分相对更复杂, 对之知之甚少.

\section{1 我国湖泊磷形态分析动态}

国家“十五”期间重点治理的三大湖泊是江苏太湖、安徽巢湖和云南滇池. 过去的五年中,在国家重点 基础研究和发展计划与中国科学院知识创新工程重大项目支持下, 湖泊富营养化问题特别是与磷形态相关 研究达到空前的热度. 从地域上看, 以长江中下游浅水湖泊特别是太湖、巢湖、龙感湖和武汉东湖的相关研 究比较突出 ${ }^{[7-15]}$. 而对于中国西部、南方和北方的湖泊,尽管也有些研究报道,如云贵高原浅水湖泊云南滇 池和洱海 ${ }^{[16-18]}$ 、深水湖泊贵州红枫湖和百花湖 ${ }^{[19,20]}$ 、福建山区深水湖库 ${ }^{[21]}$ 和北京密云水库 ${ }^{[22]}$ 等, 但是相 对较少. 不同污染状况和生态系统状况 (草型、藻型) 的湖区沉积物中磷的地球化学形态及其分布存在较大 的差异 ${ }^{[9,14]}$.

目前国内湖泊磷形态分析方法五花八门,但基本上是参考国外研究中发展的方法,没有新突破. 例如, Ruttenberg $^{[4]}$ 提出的 SEDEX 连续提取法或其改进方案 ${ }^{[11,14,19]}$ 、Golterman ${ }^{[5]}$ 提出的鳌合剂 EDTA 连续提取 法 $^{[8,23]}$ 、Ruban 等 ${ }^{[6]}$ 提出的 SMT 标准测试程序 ${ }^{[10,21]}$ 等等. 由于不同的分级分离方法得到的磷形态不一致, 因此各个湖泊沉积物的磷形态可比性不够强. 可喜得是, 朱广伟和秦伯强 ${ }^{[24]}$ 对 SEDEX 连续提取改进方案 在实际应用中出现的一些问题进行了探讨,提出水系沉积物标准物质 GSD-12 可以考虑作为淡水水体沉积 物磷形态分级的标准物质. 当然这一举措还需要一个过程,但对于推进全国湖泊磷形态调查和比较研究有 着重要的意义. 另外, 对于科学研究来说, 选择合适的形态分析法, 关键要看准沉积物自身的属性以及需要 解决的科学问题,而不是盲目应用. 例如,如果需要探讨钙质沉积物中磷成岩过程或环境地球化学意义,可 能 SEDEX 法及其改进方案比较适合 ${ }^{[19,24]}$; 而探索有机磷形态在水体富营养化过程中所起作用, 可能 EDTA 法比较合适 ${ }^{[8]}$; 探索磷形态来源的话, 可能 SMT 法比较合适 ${ }^{[10]}$, 如图 1 所示太湖、巢湖和龙感湖沉积物中 主要磷形态百分比分布情况 ${ }^{[25]}$. 沉积物中较高的 Fe/Al-P 百分数可能主要取决于邻近城市的污水排放 (图 1 的 B 区) ; 湖水出口附近沉积物有较高比例的 Ca-P (多为自生源), 且与较高的砂组分比例呈显著正相关 (图 1 的 $\mathrm{A}$ 区).

\section{2 湖泊水体沉积物磷形态转化过程及其影响因素}

中国东部浅水湖泊表层沉积物中潜在的磷源与水体相比是相当巨大的 ${ }^{[9,26]}$. 这意味着只要有极少量 的磷释放就可以对湖泊水体磷酸盐浓度产生显著影响. 通常, 浅水湖泊表层沉积物间隙水中溶解态磷酸盐 很容易通过沉积物再悬浮的扰动作用而扩散进人上覆水体, 因此在内源磷释放过程中, 它可能扮演着重要 的角色. 最近研究 ${ }^{[27]}$ 发现, 长江中下游太湖、巢湖和龙感湖等湖泊沉积物间隙水中, 差基磷灰石的沉淀过程 不是溶解态磷酸盐浓度的控制因素; 在某些磷负荷较高的湖泊沉积物或者还原性沉积物中, 蓝铁矿的形成 有可能会影响磷酸盐浓度. 但总体来看, 纯粹的磷酸盐矿物的沉淀/溶解过程并不是这三个浅水湖泊沉积 物/水界面的磷迁移转化的主要控制因素. 水体沉积物及间隙水中磷形态转化过程除了受羟基磷灰石、磷铝 石、红磷铁矿和蓝铁矿等矿物以及密切相关的无定形水合物相态的沉淀/溶解反应影响外,还应涉及以下几 


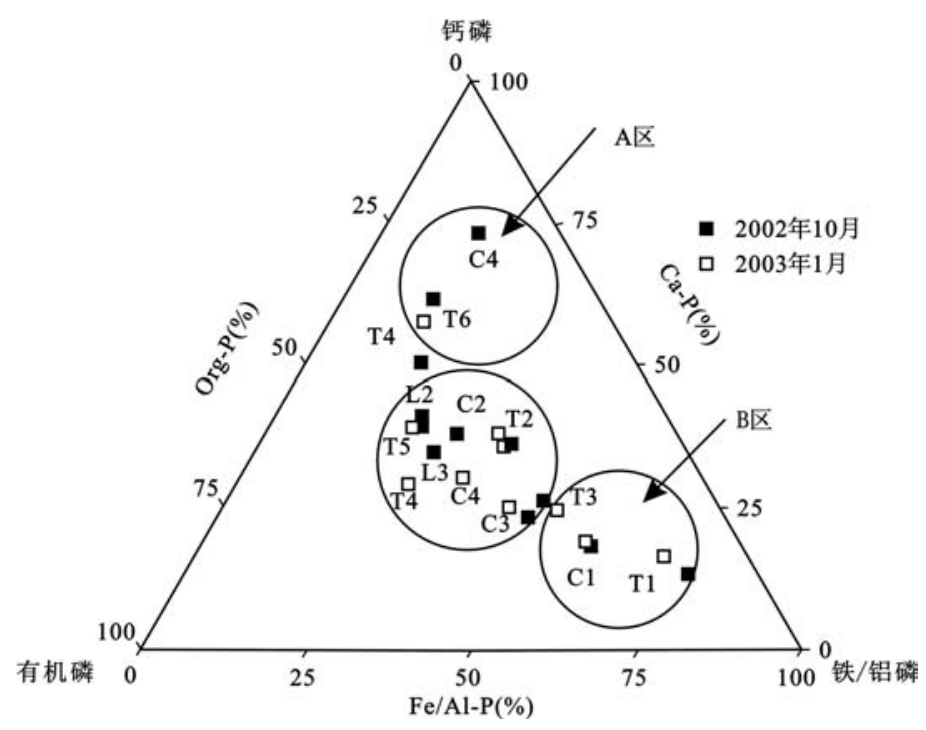

图 1 太湖 $(\mathrm{T})$ 、巢湖 $(\mathrm{C})$ 和龙感湖 $(\mathrm{L})$ 沉积物中磷形态百分比分配三角图 ${ }^{[25]}$

A 区: 靠近湖水出湖区; B 区:城市污水人湖区

Fig. 1 Triangle graphics of the percentage distribution of $\mathrm{P}$ forms in the sediments of Lakes Taihu(T), Chaohu(C), Longganhu(L) ( A : near the outlet of lake water; B: near the inlet of urban wastewater)

条主要途径.

\section{1 氧化 - 还原条件改变引起铁结合态磷的溶解或解吸}

沉积物 - 水界面的 Fe、Mn 循环受到氧化- 还原环境的控制, 沉积物中铁结合态磷会因为铁的还原溶 解而释放 ${ }^{[19]}$. 即使磷是无定形的铁/铝氧化物表面的吸附态, 氧化 - 还原条件改变时也能解吸出来 ${ }^{[11,20]}$. 在太湖的研究表明, 悬浮物沉降过程中铁结合态磷发生形态转化, 成为藻类生长的磷营养源 ${ }^{[12]}$, 可能是氧 化 - 还原条件改变的缘故. 目前国内对浅水湖泊水/沉积物氧化 - 还原反应的研究工作不多, 尤其是微生物 介人了这些过程, 如在还原条件或缺氧条件下沉积物中细菌能快速吸收和释放磷 ${ }^{[28]}$, 使得有关界面磷的释 放作用机制更为复杂 ${ }^{[29,30]}$, 是值得国内进一步研究的重要方向.

\section{$2.2 \mathrm{pH}$ 值变化会引起钙、铁结合态磷的溶解或解吸}

一般来说, $\mathrm{pH}$ 值的降低会引起钲磷酸盐与碳酸钙共沉淀的溶解. 相当多的实验证据表明表层沉积物的 磷释放受沉积物上覆水的 $\mathrm{pH}$ 值控制 ${ }^{[31]}$, 因此湖泊下层水体的酸化将会导致磷酸盐的释放. 需要注意的是: 这一过程的发生并不一定需要氧化 - 还原电位变化或氧的损耗 ${ }^{[32,33]}$. 有时表层沉积物中硫酸盐的还原可 引起 $\mathrm{pH}$ 值高达 9.9 , 它能溶解吸附在 $\mathrm{Fe}(\mathrm{III})$ 上的磷酸盐. 在日本琵琶湖富含硫化物的沉积物中蓝铁矿的 溶解导致孔隙水中磷酸盐浓度超过 $3 \mathrm{mg} / \mathrm{L}^{[34]}$.

如图 2 比较了东部浅水湖泊不同类型沉积物 (主要是磷形态比例、有机质含量、活性铁铝含量等存在差 异) 在经历 $\mathrm{pH}$ 值变化时表现出不同的磷释放模式 ${ }^{[35]}$. Fe-P/Ca-P 比值小于 0.5 的沉积物在较低 $\mathrm{pH}$ 值时可 达到较高的磷释放强度, 这些沉积物应当考虑酸化引起的磷释放风险; 而 $\mathrm{Fe}-\mathrm{P} / \mathrm{Ca}-\mathrm{P}$ 比值较高的沉积物在 较高 $\mathrm{pH}$ 值时可达到较高的磷释放强度, 相应地, 那些沉积物应当考虑碱化引起的磷释放风险. 后来, 中国 环境科学研究院的学者对太湖各湖区的不同类型沉积物进行研究时, 也发现了类似的规律 ${ }^{[36]}$. 黄清辉 ${ }^{[27]}$ 提出沉积物中 Fe-P/Ca-P 比值可作为鉴别酸化或碱化引起的磷释放的简单指数, 尽管沉积物中磷的不同释 放模式可能在很大程度上取决于活性铁铝和有机质的含量.

\section{3 有机质降解或有机磷的矿化}

铁锰结合态磷的迁移是贫营养湖泊中磷释放的最重要机制, 而近期沉积的活性有机磷组分却是富营养 


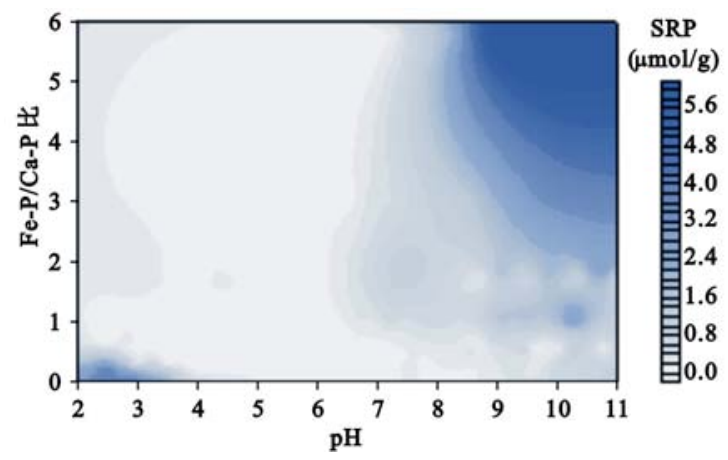

图 2 不同类型沉积物磷释放对 $\mathrm{pH}$ 值、铁磷/钙磷比变化的响应 ${ }^{[35]}$

Fig. 2 Soluble reactive phosphorus(SRP) release from different types of sediments in response to the changes of both $\mathrm{pH}$ value and $\mathrm{Fe}-\mathrm{P} / \mathrm{Ca}-\mathrm{P}$ ratio

湖泊磷释放的主力 ${ }^{[37]}$. 沉积物有机磷多数以磷酸酯 (包括肌醇六磷酸)、磷脂、核酸、磷蛋白和磷酸糖类以及 一些未知的化合物等形态出现 ${ }^{[38]}$, 其中肌醇六磷酸是沉积物中有机磷的重要形态, 含量相当可观, 大约从 $30 \mu \mathrm{g} / \mathrm{g}$ 变化到 $150 \mu \mathrm{g} / \mathrm{g}^{[39]}$. 在需氧或厌氧降解过程中肌醇六磷酸被有效地矿化成无机磷 ${ }^{[40]}$, 其矿化程度 和速率与氧化还原条件极为相关. 沉积物中肌醇六磷酸的来源与归宿仍是个谜, 但是沉积物中含活性肌醇 六磷酸酶的细菌的存在意味着细菌的积极参与 ${ }^{[41]}$. 有机质的沉积和降解是控制沉积物孔芯中磷酸盐分布 的主要机制 ${ }^{[42]}$.

在我国湖泊研究中,王雨春等 ${ }^{[20]}$ 发现深水红枫湖的沉积磷在最终埋藏前可能发生非常剧烈的形态转 化和再迁移, 尤其是有机磷和铁结合态磷的成岩改造可能是湖泊系统磷循环质量平衡的重要方面. 李军 等 ${ }^{[11]}$ 在太湖五里湖研究中发现, 沉积物在早期成岩作用过程中, 湖泊内源自生有机质发生降解时优先释放 有机磷; 而铁结合态磷在氧化 - 还原条件变化的情况下, 能够通过沉积物/水界面被再次释放到水体中去. 另外, 黄清辉等 ${ }^{[8]}$ 在对我国东部太湖、巢湖和龙感湖等浅水湖泊的研究中发现, 沉积物中酸可提取有机磷 的释放可能是导致湖泊富营养化的重要过程之一. 滑丽萍等 ${ }^{[23]}$ 在对北方湖泊白洋淀的研究中也提出一致 的看法.

\section{4 微生物转化作用}

细菌等微生物在沉积物磷的释放与固定中也可起重要作用 ${ }^{[41]}$. 沉积物细菌或沉水植物根系对磷的吸 收、䛎存和释放 (包括铁结合态磷的厌氧释放) 起重要作用 ${ }^{[28,43]}$. 例如, 在 Erken 湖, 某种蓝细菌对夏季内源 磷负荷贡献显著 ${ }^{[4]}$. 在加拿大富营养化湖泊沉积物孔芯中, 铁铝吸附和共沉淀的磷较少, 磷释放可能受到 磷灰石溶解与细菌新陈代谢控制 ${ }^{[45]}$.

国内湖泊在微生物对磷形态转化作用方面的研究较少,但也有一些报道. 例如,夏学惠等微生物在滇池 沉积物中磷的循环过程中起了重要作用 ${ }^{[16]}$. 乳酸菌对不溶性磷酸盐的分解, 使湖泊中可溶磷含量增高; 而 聚磷菌对磷元素的富集以及聚磷菌死亡后发生有机磷的矿化作用, 是湖泊中水合磷酸盐矿物沉积的重要途 径. 邹迪等 ${ }^{[46]}$ 研究发现附生假单胞菌的存在能促进铜绿微囊藻的生长, 并可以将微囊藻不易直接吸收的 磷形态 (如 $\beta$-甘油磷酸钠、磷酸䥻和卵磷脂等) 转化为磷酸盐等物质供微囊藻利用, 碱性磷酸酶在微囊藻和 $\mathrm{X}$ 菌利用大分子有机磷的过程中起重要作用.

此外, 国内湖泊研究还发现, 浅水湖泊中水生生物状况、风浪扰动状况对沉积物中磷的地球化学行为有 至关重要的影响 ${ }^{[7,47]}$; 而光照强度通过影响底栖藻类吸收沉积物释放磷的过程而限制了其进人上覆

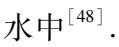

\section{3 湖泊水体沉积物磷的潜在效应}

国内对湖泊沉积物磷的潜在效应主要表现在磷释放风险和生物有效性研究上. 磷释放风险多数是从化 
学试剂提取的活性较强的磷形态含量来评估的 ${ }^{[14]}$, 也有发展磷释放风险指数来评价的. 例如, 黄清辉等 ${ }^{[49]}$ 提出由磷吸附指数和磷吸附饱和度等因素构成的磷释放风险指数概念, 并对磷诱发的太湖富营养化风险进 行预测, 并在巢湖、龙感湖的预测上得到初步验证 ${ }^{[27]}$. 另外, 在湖泊磷的生物有效性研究中, 一般以藻类生 长潜力来评估水体磷形态的生物有效性 ${ }^{[50]}$, 而化学提取法常用于间接估算沉积物生物有效磷含量, 如西 湖 $^{[51]}$ 和太湖 ${ }^{[51,52]}$. 最近我国在利用磷汇 ( P sink) 方法评估水和沉积物中磷的生物有效性上取得些新突破, 例如,利用氧化铁/醋酸纤维素复合膜 $(\mathrm{FeO} / \mathrm{CAM})$ 估算生物有效磷的方法 ${ }^{[53]}$,这种方法于 2004 年在太湖 梅梁湾现场得到了初步的应用 ${ }^{[26]}$.

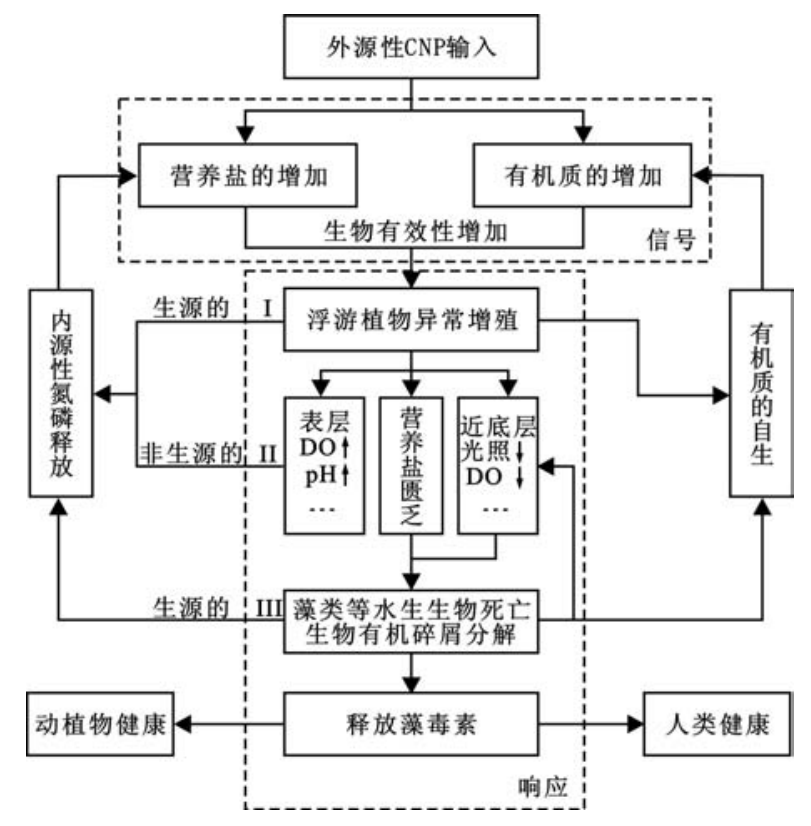

图 3 浅水湖泊内源释放与富营养化互动过程的概念化模式

Fig. 3 Concept model of the interaction between internal release and eutrophication of shallow lakes

湖泊内源释放 (特别是浅水湖泊内源磷的释放) 与富营养化过程之间不是简单的信号 - 响应函数关 系, 而可能存在一种互动的机制 (如图 3 所示). 在湖泊富营养化过程中, 随着外源性和内源性的营养盐和 有机质的增加, 它们的生物有效性也得到增强, 刺激了浮游植物的异常增殖. 其新陈代谢活动产生的氮磷和 有机质(如图 3 中的过程 I), 一部分以内源形式参与再循环过程. 蓝藻水华爆发可以通过改变 $\mathrm{pH}$ 值引发湖 泊内源磷的释放 ${ }^{[26]}$. 因为浮游植物的初级生产过程会消耗大量 $\mathrm{CO}_{2}$, 引起表层水体 $\mathrm{pH}$ 值升高, 促进颗粒物 中铁磷的释放 (如图 3 中的过程 II). 在富营养的浅水湖泊中, 过度生长的藻类会遮盖水面阻挡光照, 导致水 下水草死亡. 当藻类因缺乏营养盐而死亡分解时, 底部的生物有机碎屑在微生物的参与下进行分解( 如图 3 中的过程 III), 氧气会消耗殆尽, 产生的氮磷或有机质又会重新进入湖水中 (也即增强信号), 刺激着新的生 态响应. 由于水草可为水生动物提供食物和栖息地, 因此随着水草的死去, 它们的产卵与抚育的栖息地就遭 到破坏,水鸟也会因此缺乏食物; 而溶解氧是水体大多数生物 (如鱼类、螃蟹等) 不可或缺的; 藻类死亡分解 时还会产生藻毒素. 这样, 不仅水生生物的生命和多样性受到威胁, 还危及那些赖以湖泊生存的居民健康及 生命安全. 当然, 水动力、风浪等因素的扰动作用将会在很大程度上刺激内源性营养盐的释放 ${ }^{[47]}$, 也即增 强信号, 从而引发新的生态响应.

\section{4 结语}

近年来, 国内湖泊水域磷形态转化及其潜在效应研究比较集中在长江中下游的浅水湖泊,对我国西部、 
南方和北方的湖泊特别是深水湖泊的研究相对较少, 而对咸水湖或河口海岸带泻湖生态系统研究偏少. 另 外,在湖泊水域磷形态分析方法上没有取得突破性进展,有时甚至盲目应用; 磷形态转化过程研究上取得的 进展主要表现是发现了不同类型沉积物对 $\mathrm{pH}$ 的响应模式, 而对生物活动影响研究相对较弱; 在潜在效应 方面, 对磷释放风险和生物有效性评估方法也有些积极的探索研究. 尽管国内对众多湖泊沉积物/水界面 磷的形态和迁移转化机制做了许多有益的探索, 也提出了不少假设和新方法, 但是仍然需要更多的实验数 据的证明.

致谢: 感谢中国科学院太湖湖泊生态系统野外观测站的同志多年来给予的帮助, 感谢匿名评委提出的宝贵 修改意见和建议.

\section{5 参考文献}

[1] Wang Z J. A Speciation Study of Phosphorus in the Interstitial Water of Lake Geneva, Switzerland. Proceedings of $3^{\text {rd }}$ International Symposium on the Interaction between Sediment and Water, August 1984, Geneva, Switzerland.

[2] Han S H, Wang Z J, Zhuang Y H, et al. Phosphine in Various Matrixes. J Environ Sci, 2003, 15(3) : 339 -341 .

[3] Niu X J, Geng J J, Wang X R, et al. Temporal and spatial distributions of phosphine in Taihu Lake, China. The Science of the Total Environment, 2004, 323(1 - 3): $169-178$.

[4] Ruttenberg K C. Development of a sequential extraction method for different forms of phosphorus in marine sediments. Limnol \& Oceanogr, 1992, 37 : 1460 - 1482.

[5] Golterman H L. Fractionation of sediment phosphate with chelating compounds: a simplification, and comparison with other methods. Hydrobiologia, 1996, 335: 87 - 95 .

[6] Ruban V, Brigault S, Demare D, et al. An investigation of the origin and mobility of phosphorus in freshwater sediments from Bort-Les-Orgues Reservoir, France. Journal of Environmental Monitoring, 1999, 1(4) : $403-407$.

[7] 朱广伟,高 光,秦伯强等. 浅水湖泊沉积物中磷的地球化学特征. 水科学进展, 2003, 14 (6): 714 -719 .

[8] 黄清辉, 王东红, 王春霞等. 沉积物中磷形态与湖泊富营养化的关系. 中国环境科学, 2003, 23(6): $583-586$.

[9] 朱广伟, 秦伯强, 高 光等. 长江中下游浅水湖泊沉积物中磷的形态及其与水相磷的关系. 环境科学 学报, 2004, (3):381-388.

[10] 黄清辉, 王东红, 王春霞等. 太湖梅梁湾和五里湖沉积物磷形态的垂向变化. 中国环境科学, 2004, 24(2) : $147-150$.

[11] 李 军, 刘丛强, 王仕禄等. 太湖五里湖表层沉积物中不同形态磷的分布特征. 矿物学报, 2004, (4) : $405-410$.

[12] 孙晓杭, 张 昱, 杨 敏等. 太湖悬浮物磷的形态分布特征. 安全与环境学报. 2005, 5(4):19-22.

[13] Fu Y Q, Zhou Y Y, Li J Q. Sequential fractionation of reactive phosphorus in the sediment of a shallow eutrophic lake - Donghu Lake, China. Journal of Environmental Sciences, 2000, 12(1) : 57 - 62 .

[14]朱广伟, 秦伯强, 张 路. 长江中下游湖泊沉积物中磷形态及藻类可利用量. 中国科学: D 辑, 35 (增 刊 II) : $24-32$.

[15] Wang S R,Jin X C,Zhao H C, et al. Phosphorus fractions and its release in the sediments from the shallow lakes in the middle and lower reaches of Yangtze River area in China. Colloids and Surfaces A: Physicochemical and Engineering Aspects,2006, 273: 109 - 116.

[16] 夏学惠, 东野脉兴, 周建民等. 滇池现代沉积物中磷的地球化学及其对环境影响. 沉积学报, 2002,20 (3) : 416 - 420 . 
[17] 胡 凯, 柯鹏振, 吴永红等. 高原浅水湖泊沉积物中磷、氮形态化学研究. 长江流域资源与环境, $2005,14(4): 507-511$.

[18] 王雨春, 此里能布, 马根连等. 洱海沉积物磷的化学赋存形态研究. 中国水利水电科学研究院学报, 2005 , (2) : $150-155$.

[19] 王雨春, 万国江,王仕禄等. 红枫湖、百花湖沉积物中磷的存在形态研究. 矿物学报, 2000, 20(3):273 -278 .

[20] 王雨春, 马 梅, 万国江等. 贵州红枫湖沉积物磷赋存形态及沉积历史. 湖泊科学, 2004, 16 (1): 21 -27 .

[21] 苏玉萍, 郑达贤, 庄一廷等. 南方内陆富营养化湖泊沉积物磷形态特征研究. 农业环境科学学报, $2005,24(2): 362-365$.

[22] 刘 汶, 刘晓端, 徐 清等. 密云水库沉积物中磷的形态和分布特征. 岩矿测试, 2003, 22(2): $81-$ 85.

[23] 滑丽萍, 李贵宝, 华 珞等. 不同芦苇生境下白洋淀底泥磷形态分析研究. 南水北调与水利科技, $2005, \mathbf{3}(2): 29-32$.

[24] 朱广伟,秦伯强. 沉积物中磷形态的化学连续提取法应用研究. 农业环境科学学报, 2003, 23(3): 349 -352 .

[25] Huang Q H, Wang Z J, Wang D H et al. Origins and Mobility of Phosphorus forms in the Sediments of Lakes Taihu and Chaohu, China. Journal of Environmental Science and Health, Part A, 2005, 40(1) : 91 102.

[26] 黄清辉,王子健, 王东红等. 夏季梅梁湾水体中生物有效磷的分布及来源. 中国科学 (D 辑), 2005, 35 (增刊 II) : $131-137$.

[27] 黄清辉. 浅水湖泊内源磷释放及其生物有效性一一太湖、巢湖和龙感湖为例 [ 学位论文]. 北京: 中 国科学院研究生院, 2005.

[28] Gacther R, Myer J. The role of microorganisms in mobilization and fixation of P in sediments. Hydrobiologia, 1993, 253 : $103-121$.

[29] Lazzretti M A, Hanselmann K W. The role of sediments in the phosphorus cycle in large Lake Lugan: II. Seasonal and spatial variability of microbiological processes at the sediment-water interface. Aquatic Sciences $, 1992, \mathbf{5 4}(3 / 4): 285-299$.

[30 ] Lavery P S, Oldham C E, Ghisalberti M. The use of Fick's First Law for predicting porewater nutrient fluxes under diffusive conditions. Hydrological Processes, 2001, 15(13) : 2435 - 2451.

[31] Koski Vahala J, Hartikainen H, Tallberg P. Phosphorus mobilization from various sediment pools in response to increased pH and silicate concentration. J Environ Qual,2001, 30(2) : $546-552$.

[32] Golterman H L. The distribution of phosphate over iron-bound and calcium-bound phosphate in stratified sediments. Hydrobiologia, 1998, 364: $75-81$.

[33] Borovec J. Chemical composition and phosphorus fractionation of sediments in the Bohemian Forest lakes. Silva Gabreta, 2000, 4: 179 - 184.

[34] Murphy T, Lawson A, Kumagai M, et al. Release of phosphorus from sediments in Lake Biwa. Limnology, $2001,2: 119-128$.

[35] Huang Q H, Wang Z J, Wang C X, et al. Phosphorus release in response to $\mathrm{pH}$ variation in the lake sediments with different ratios of iron-bound $\mathrm{P}$ to calcium-bound P. Chemical Speciation and Bioavailability, $2005,17(2): 55-61$.

[36] Jin X C, Wang S R, Pang Y, et al. Phosphorus fractions and the effect of $\mathrm{pH}$ on the phosphorus release of the sediments from different trophic areas in Taihu Lake, China. Environmental Pollution, 2006, 139: 288 -295 . 
[37] Gonsiorczyk T, Casper P, Koschel R. Phosphorus-binding forms in the sediment of an oligotrophic and an eutrophic hardwater lake of the Baltic Lake district (Germany). Water Science \& Technology, 1998, 37 (3): $51-58$.

[38] Ingall E D, Schroeder P A, Berner R A. The nature of organic phosphorus in marine sediments: new insights from ${ }^{31}$ P-NMR. Geochim Cosmochim Acta, 1990, 54: 2617 - 2620.

[39] De Groot C J, Golterman H L. On the presence of organic phosphate in some Camargue sediments: evidence for the importance of phytate. Hydrobiologia, 1993, 252: $117-126$.

[40] Suzumura M, Kamatani A. Mineralization of inositol hexaphosphate in aerobic and anaerobic marine sediments-implications for the phosphorus cycle. Geochimica et Cosmochimica Acta,1995, 59(5) : 1021 - 1026.

[41] Golterman H L. Fractionation and bioavailability of phosphorus in lacustrine sediments: a review. Limnetica, 2001, 20(1): $15-29$.

[42] Kruusement K, Punning J M. Distribution of phosphorus in the sediment core of hypertrophic Lake Ruusmaee and some palaeoecological conclusions. Proceedings of the Estonian Academy of Sciences, Biology Ecology, $2000,49(2): 163-176$.

[43] Christensen K K, Jensen H S, Andersen F, et al. Interferences between root plaque formation and phosphorus availability for isoetidsin sediments of oligotrophic lakes. Biogeochemistry, 1998, 43(2) : 107 - 128.

[44] Pettersson K. Mechanisms for internal loading of phosphorus in lakes. Hydrobiologia, 1998, 373 : 1 -3.

[45] Burley K L, Prepas E E, Chambers P A. Phosphorus release from sediments in hardwater eutrophic lakes: the effects of redox-sensitive and -insensitive chemical treatments. Freshwater Biology, 2001 , 46( 8) : 1061 -1074 .

[46] 邹 迪, 肖 琳, 杨柳燕等. 不同形态磷源对铜绿微囊藻与附生假单胞菌磷代谢的影响. 环境科学, $2005,26(3): 118-121$.

[47] 朱广伟, 秦伯强, 高 光. 风浪扰动引起大型浅水湖泊内源磷暴发性释放的直接证据. 科学通报, $2005, \mathbf{5 0}(1): 67-71$.

[48] 姚 扬, 金相灿, 姜 霞等. 光照对湖泊沉积物磷释放及磷形态变化的影响研究. 环境科学研究, 2004,17 (z1): $30-33$.

[49] 黄清辉, 王子健, 王东红等. 太湖表层沉积物磷的吸附容量及其释放风险评估. 湖泊科学, 2004, 16 (2) : $97-104$.

[50] 周培疆, 郑振华, 余振坤等. 普通小球藻生长与武汉东湖水体磷形态的相关研究. 水生生物学报, $2001,(6): 571-576$.

[51] Zhou Q X, Gibson C E, Zhu Y M. Evaluation of phosphorus bioavailability in sediments of three contrasting lakes in China and the UK. Chemosphere, 2001, 42(2): $221-225$.

[52] 张 路,范成新, 朱广伟等. 长江中下游湖泊沉积物生物可利用磷分布特征. 湖泊科学, 2006,18 (1): $36-42$.

[53] 黄清辉, 王东红, 王春霞等. 沉积物和土壤中磷的生物有效性评估新方法. 环境科学, 2005, 26(2) : $206-208$. 